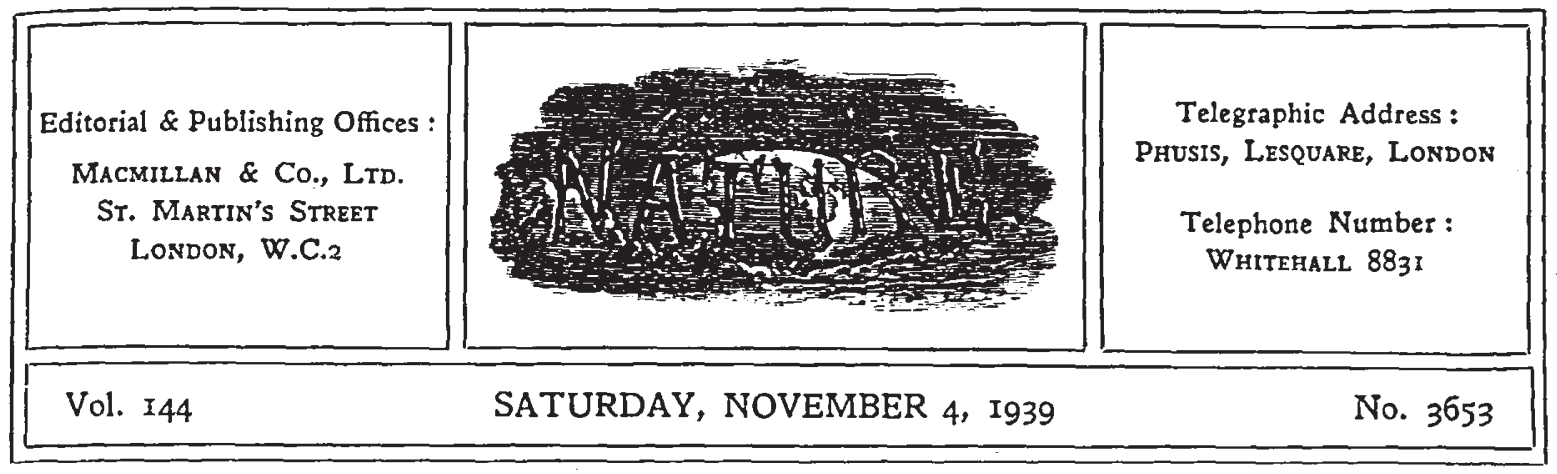

\title{
SCIENCE MEETINGS IN WAR-TIME
}

W AR conditions, though they may make un. precedented demands on our scientific knowledge and technical skill, throw us, in some of their aspects, back to simpler ways of living and to the use of more primitive appliances. The horse has come into his own again; venerable carriages, bearers of long-forgotten names-who, in this twentieth century generation, can readily distinguish between barouche, victoria, cabriolet and whisky ?-appear in provincial streets and country roads, astonishing all but the oldest inhabitants; and we find new merits in the performances of (duly-shaded) hurricane lamps and wax candles. A railway journey, prolonged after sunset, adds a new terror to life for those of us who are not content to sit and think. We look back with something of envy to those spacious days when our grandparents travelled luxuriously and read in comfort by the light of some candle-bearing contraption which could be hooked to the back of a railway-carriage seat. Meetings, even in neutral and reception areas, are not to be attended without due consideration of the perils associated with a journey through 'blacked-out' streets.

Nevertheless, it is a matter of no small importance that our scientific societies, restricted and re-orientated as some of their activities necessarily must be, should carry on their work to the fullest extent possible under these new conditions of life. A hasty and ill-considered cutting-down of work brings many evils in its train. Fellows tend to forget the existence of the society, and its membership roll falls off in consequence; the economic life of certain sections of the community suffers unnecessary and undeserved hardships; the world at large fails to realize that a scientific society can play as weighty a part in war as in peace. It was never more important than it is now to conserve and to extend our mental resources; to meet and to exchange ideas; to cultivate a sane and objective outlook on the problems of a world poised insecurely on the brink of chaos.

Travel is difficult; so it was two centuries ago, and provincial towns formed, each for itself, societies for the advancement of learning. Members are scattered; and does not this very fact ensure the presence, in most of our large towns to-day, of men and women sufficiently interested in their different branches of knowledge to welcome an opportunity to exchange views and to seize an hour for the friendly discussion of intellectual problems? Cinemas may be filled to.day-and it is all to the good that they should be-even in evacuation areas; there is little room to doubt that, if the opportunity be given them, scores of scientific workers would welcome the chance to discuss the ever-changing problems of their sciences, and to find, now and again, a period of their day which would be free from the problems of war.

The past has its lessons for the present ; material conditions for travel and for social intercourse were more difficult in $\mathbf{1 7 7 0}$ than they are now, and we find in consequence that the greater cities of Britain tended each to cultivate a social life of its own, a social life that was dominated, in many instances, by the bearers of names now honoured in our country's history. The intellectual standard of our university towns in that age has not passed uncriticized. Gibbon has told us of Oxford; Byron, at a slightly later period, had some unkind things to say of the Cambridge fellows:

\footnotetext{
"Where on Cam's sedgy banks supine they lie, Unknown, unhonoured live, unwept-for die : Vain as their honours, heavy as their ale, Sad as their wit, and tedious as their talo";
} 
Johnson made shrewd thrusts at Scottish learning. But these are partisan views, and an impartial observer will find that the contributions of the university towns of that age to the advancement of learning and to the critical discussion of those advances were by no means unsubstantial. Other towns, as we have noted, made their contribution mainly through one or two families of dominating interests. The Taylors and Martineaus made such a group at Norwich; the Roscoes at Liverpool ; and at Birmingham above all, Boulton, Watt, Small, Erasmus Darwin, Priestley and Wedgwood formed a group whose contributions to knowledge were a considerable factor in the development of eighteenth century science.

This group had, as early as the 1760 's, formed the excellent habit of dining at each other's houses monthly "to exchange views relating to literature, art and science; each contributing his quota of entertainment and instruction". For the con. venience of the members the meeting nights were fixed for evenings as near to that of the full moon as possible. Art had not then provided an effective means for lightening the darkness of the streets and lanes; why not make use of the illumination provided by Nature?

It is no part of our purpose to tell in detail the fortunes of the Lunar Society as it was happily named-it is sufficient to say that many dis. coveries of the first importance were discussed at its meetings before they were communicated in regular fashion to the Royal and to other societies ; that the "learned Lunatics", as Erasmus Darwin styled his fellow-members, helped to finance much of Priestley's work; and that even when the Society, by death and dispersal, had lost most of its members and was moribund, Leonard Horner could say of it, in 1809, that "the remnant of the Lunar Society and the fresh remembrance in others of the remarkable men who composed it, are very interesting. The impression which they made is not yet worn out, but shows itself, to the second and third generation, in a spirit of scientific curiosity and free inquiry which even yet makes some stand against the combined forces of Methodism, Toryism and love of gain."

The spirit of free inquiry has to-day to encounter forces other than those which excited the concern of Horner, and the learned societies of the democratic countries-indeed, of all countriesmay even to-day learn something from the zeal and unselfishness which informed the work of the Lunar Society. In one small matter they might very well profit by the return to some of the conditions of life as it was lived in the days of Erasmus Darwin, and hold meetings on nights near the date of the full moon. If secretaries of the learned societies of London were to consult their almanacs and maps of Britain, they would surely find times and places favourable for the holding of informal meetings suited to present-day needs, as the Linnean Society is already doing (see page $778)$; and the Lunar Society would enter on a new lease of life.

\section{NATURAL AND POLITICAL PHILOSOPHIES}

\section{Science and Politics in the Ancient World}

By Prof. Benjamin Farrington. Pp. 244. (London : George Allen and Unwin, Ltd., 1939.) 10s. 6d. net.

IN Plato's City-State, the ruler or lawgivers were 1 held to be justified in inventing or approving useful or pious lies if the best minds were convinced that the community was incapable of understanding the truth. The State had to decide what was good for the people to know and accept, whether relating to governmental legislation or religious beliefs. The right appreciation of truth was regarded as the prerogative of a select fow and. as popular intelligence was not prepared for enlightenment, it was inexpedient to teach the masses anything which would disturb either their social complacency or superstitions. Socrates himself, to whom many of the political principles represented in Plato's "Republic" can be ascribed, was condemned to die because he would not cease to "corrupt the young" by his teaching; and Galileo might have saved himself from imprisonment by ceasing to disturb the traditional teaching of the Church as to the stability of the earth in the centre of the universe.

It is with repercussions of this kind in the ancient worlds of Greece and Rome that Prof. Farrington is concerned in his critical survey of philosophies of science in relation to political action from the period of Thales and Anaximander in the sixth century B.c., through Empedocles, Leucippus and Democritus, creators of theories of atomism, which, with Hippocratic medicine, are 